\title{
DUTIES AND RESPONSIBILITIES OF DIRECTORS OF MUTUAL FUNDS
}

\author{
ALfred JARETZKi, JR.*
}

\section{INTRODUCTION}

This article will deal with the principal duties and responsibilities of directors of so-called mutual funds. It is general in scope and does not attempt to discuss or even touch upon all possible legal refinements in the area. It is intended to be of use to the lay reader as well as a summary discussion for the lawyer.

The term "mutual fund" is now popularly used to refer to an open-end as distinguished from a closed-end investment company. ${ }^{1}$ Each is a form of "investment company"-a company engaged in the business of investing and re-investing its funds-and the shareholder of each, assuming a single class of stock, has in effect an undivided interest in the property of the company. This consists primarily of securities and cash items. As distinguished from a closed-end company, the openend company or mutual fund is one in which the shareholder may at any time require the company to repurchase his shares for an amount equal to or slightly discounted from the pro rata value of the underlying assets held by the company. ${ }^{2}$ Most mutual funds are also continuously engaged in issuing new shares to the public at net asset value plus a sales charge. ${ }^{3}$ In contrast the closed-end company, like the conventional corporation, issues new shares of stock only occasionally. Its shares are traded in the open market, either on a stock exchange or over-the-counter, and may sell at prices above or below net asset value, presently generally somewhat below.

Because of the continuous sales and redemptions of mutual fund shares, the

* A.B. I913, LL.B. 1916, Harvard University. Member of the New York bar. The author, who has been engaged extensively in matters involving investment company law and regulation during the past thirty-five years, participated in the drafting of the Investment Company Act of 1940 .

The author wishes to acknowledge the assistance of his associate, Robert A. Krantz, Jr., A.B. I954, Yale University; LL.B. I960, Harvard University. Member of the Colorado and New York bars.

2 In the Investment Company Act of 1940,54 Stat. 789 (1940), as amended, 15 U.S.C. \$\$80a-I to -52 (1958), as amended, I5 U.S.C. $\$ \$ 80 a-2(a)(37)$ to -39 (a) (Supp. IV, 1963) [hereinafter cited as Inv. $\mathrm{Co}$. Act], these companies are referred to as "management" investment companies, as distinguished from facc-amount certificate companies and unit investment trusts. Inv. Co. Act $\$ 4$. Although the latter two types are also "investment companies" within the meaning of the Investment Company Act, they are not discussed in this article. For a comprehensive exposition of the Investment Company Act, see Jarctzki, The Investment Company Act of 1940, 26 WASH. U.L.Q. 303 (x94I).

As defined in the Investment Company Act of 1940, an open-end company is "a management company which is offering for sale or has outstanding any redeemable security of which it is the issuer." Inv. Co. Act $\$ 5(\mathrm{a})(\mathrm{I})$. It should be noted that some mutual funds charge a slight fee, normally about one per cent, on redemption of their shares. In extreme circumstances the right of redemption may be suspended. Inv. Co. Act $\$ 22(\mathrm{e})$.

The shares of some funds are sold at asset value without any sales load. Such funds have no distributing organization (principal underwriter) and are generally affliated with an organization engaged in the business of rendering investment advice to individual accounts. 
directors of a mutual fund have responsibilities in these respects which are not shared by directors of closed-end companies. Otherwise their duties are essentially the same and it may be assumed that this discussion of the duties and responsibilities of mutual fund directors applies in substance to those of directors of closed-end investment companies except where it relates to matters pertaining to sales and redemptions.

\section{Applicable Law}

Basically, the duties and responsibilities of a director of a mutual fund derive from the corporate laws of the applicable states. ${ }^{4}$ Of other sources to be taken into account, the primary one is the Investment Company Act of 1940. This act not only contains certain provisions bearing directly on the duties of a director, but in addition prescribes a number of standards governing the activities of investment companies to which the companies, acting through their officers and directors, must conform. With respect to the sale and distribution of the shares of the fund, further duties are imposed both by the Securities Act of $1933^{5}$ under which the shares must be registered, and by the so-called blue sky laws of the states in which the shares are to be sold. Indeed, the blue sky laws of many states, including particularly, California, Illinois, Ohio, and Wisconsin, require adherence to standards which in effect result in regulation not only of sales but also of the investment activities and basic organization of the funds. ${ }^{6}$ Wisconsin takes, and until recently Illinois took, the extreme position of not permitting an adviser of the fund to act as broker in the purchase and sale of portfolio securities. ${ }^{7}$ These and other states place limits on sales charges and overall expense ratios and a number of states require that the charter or other basic instruments of the fund contain provisions to secure a degree of diversification of the fund's portfolio and other matters. ${ }^{8}$

4 Although most mutual funds are organized as corporations under state law, a significant minority are organized as common-law trusts. In general, the trust differs from the corporation in that it is not organized under, nor is its existence derived from, any statute. Under most trust agrcements, the powers, duties and liabilities of individual trustees of mutual funds correspond closely to those of directors of corporate funds. This is appropriate. As business entities there is no reason to distinguish between the two forms. To fashion one set of standards for trustees and another for directors of the same kind of enterprise would ignore reality and accord critical weight to what the Delaware Chancellor has described as "a difference which does not really make a differcnce." Saminsky v. Abbott, I 85 A.2d 765, $77 \mathrm{r}$ (Del. Ch. 196I). The Investment Company Act defines "director" as including a trustee. Inv. Co. Act $\$ 2$ (a) (12).

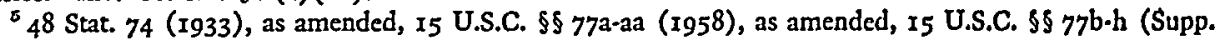
IV, 1963 ).

'Cal. Adm. Code, tit. Io, c. 3, art. 19, I CCH Blue Sky L. Rep. $\{8630$ (1963); Ill. : Rule: C., I CCH BLve SKy L. Rep. \{9 r6,781-r6,790 (1964); Ohio Reg. Q-3, 2 CCH Blue Sky L. Rep. I38,653 (1954); Wis. Adm. Code, $\$ 2.03,2$ CCH Blue Sky L. Rep. \52,623 (1962).

'Wis. Dep't of Securities, Monthly Bull. (May, 1958), 2 CCH Blue SkY L. Rep. I52,623.03 (1960); Ill. Rule C, Rule 5, I CCH Brue Sxy L. REP. I 16,785 (1964). It is understood, however, that Illinois has recently rescinded its rule in this respect.

${ }^{8}$ See, e.g., Ohio, Reg. Q-3, 2 CCH Blue Sky L. Rep. If 38,653 (1954). 
Certain sections of the Securities Exchange Act of 1934 also apply to mutual funds. ${ }^{9}$ It is neither expected nor required that each director have detailed familiarity with these provisions. In this as in many other matters he is entitled to rely upon the management and the attorneys for the fund.

\section{II}

\section{General Principles of Director Responsibility Under State Law}

At common law and under state statutes, it is fundamental that the board of directors is responsible for the management of the regular business affairs of the company. This area of responsibility normally comprehends all matters which do not involve basic changes in the corporate existence of the company, its powers or its capital structure. By statute these latter matters are reserved to the stockholder.

Within the area of its jurisdiction, the board of directors is responsible for control and general supervision of the business, for formulating its policies, and for establishing and maintaining an organization to implement these policies. This is a collective responsibility, imposed upon the directors as a board. Neither the ultimate authority nor the overall responsibility may be relinquished to others. Thus, although the board has inherent authority to delegate functions to agents and representatives, a contract by the board of directors to divest itself of all or substantially all of its powers by delegation to another is unenforceable.

In the fulfillment of their management responsibility, the directors are under a duty to exercise a degree of care and diligence. Because they function as a board they are expected to hold and attend meetings with reasonable regularity. In the normal course of events their obligation to be informed as to the condition and affairs of the business will be satisfied through their attendance and attention at meetings, where they must not only pass upon matters presented to them but when appropriate initiate inquiries into other matters. Frequently they will be called upon to examine reports circulated between meetings and occasionally to engage in other activities not requiring group action as a board. If the directors know any facts which would awaken suspicion and put a reasonable man on his guard, something more will be required. But it is clear that the director, in assuming office, does not undertake to devote any really substantial amount of his time to the business of the company, and that he exercises his function primarily at periodic meetings of the board. He is not expected to interfere individually in the actual conduct or operation of the corporation's affairs.

Neither does the law require that the directors have any special or technical talent or expertise in the business of the company. They do not hold themselves out as having better judgment than that of a reasonably prudent man of affairs or as assuring that the results of their management will be successful or even satisfactory.

${ }_{48} 8 \mathrm{Stat.} 88 \mathrm{I}$ (1934), as amended, $\mathrm{r}_{5}$ U.S.C. $\$ 578 \mathrm{a}-\mathrm{hh}-\mathrm{I}$ (1958), as amended, $\mathrm{I}_{5}$ U.S.C. $\$ 578 \mathrm{c}$ (a)-s (Supp. IV, I963). 
At least so long as they act honestly and exercise ordinary care and diligence, and within the scope of their authority, their decision will not be disturbed by the courts nor will it be made the basis of any claim against them. ${ }^{10}$

The rule is otherwise, however, in cases where the directors, or any of them, have any interest which is adverse to the corporation. In any such situation it is the duty of the interested director to disclose fully his adverse interest and then to stand aside and defer to the judgment of the disinterested directors or to the judgment of the stockholders. In so doing he does not divest himself of his duty not to overreach in any transaction with the fund of which he is a director. If the director fails to conform his conduct to these fiduciary standards, the transaction, if unfair, will be voidable at the option of the corporation.

Generally speaking, the responsibility of a director is not measured by the compensation he receives. If he undertakes to serve as a director he must discharge his obligations even though he receives no fee whatsoever. On the other hand, receipt of compensation substantially beyond the normal may indicate that the director has undertaken duties which would not otherwise be his and that additional responsibilities are imposed. ${ }^{11}$

\section{III}

\section{Operation of a Mutual Fund}

In order to understand the application to mutual fund directors of these general rules and of specific statutory provisions, it is necessary to review briefly the manner in which these funds operate. While some funds function in a conventional corporate manner with their own internal management staff, most funds conduct their business through an investment advisory or management agreement entered into with another organization, generally either a corporation or a partnership. Under the most common form of advisory agreement, the adviser provides the officers, personnel and office space of the fund and makes recommendations to the fund with respect to the purchase and sale of securities. As the officers and per-

\footnotetext{
${ }^{10}$ It has been said that a more stringent rule is applicable to directors of banks and trust companics, see, e.g., Greenfield Savings Bank v. Abercrombie, 211 Mass. 252, 255, 97 N.E. 897, 899 (1912) (savings bank); Litwin v. Allen, 25 N.Y.S.2d 667, 678 (Sup. Ct. 1940) (trust company), but even if this is so, there is no logical basis for extending this more rigorous standard to investment company directors. Investment companies are organized as ordinary business corporations or business trusts, not under such special statutory provisions as those which pertain to other types of financial institutions, and, as the Massachusetts court has stated, they involve none of the special incidents peculiar to banks. Spiegel v. Beacon Participations, Inc., 297 Mass. 398, 410-11, 8 N.E.2d 895, 904 (1937) (investment company directors subject to personal liability only for "clear and gross negligence"); Acampora v. Birkland, 220 F. Supp. 527, 550 (D. Colo. 1963) (same). In so far as the Investment Company Act is concerned, the only references to liabilities of directors of mutual funds are contained in $\S 36$, relating to "gross misconduct or gross abuse of trust," and $\S_{17}(\mathrm{~h})$, which prohibits indemnification or exculpation for "wilful misfeasance, bad faith, gross negligence, or reckless disregard of the duties involved in the conduct of his office."

${ }^{22}$ For example, all non-affiliated directors of a particular fund might reccive compensation sub. stantially beyond the normal for comparable companies, or a particular director might receive compensation greater than that of his fellow directors.
} 
sonnel of the fund are normally persons from within the advisory organization, it follows that the investment adviser in such cases will be making recommendations to persons from its own organization acting also as officers or directors of the fund. In relatively few cases the investment adviser actually manages the portfolio of the fund directly and has the authority itself to make purchases and sales on behalf of the fund, subject to the overall supervision of the fund's board of directors. Both types of arrangements are recognized in the Investment Company Act and the person acting in either of these capacities is defined as an "investment adviser."12

The act provides that an investment advisory contract must initially be approved by the vote of stockholders and that it may continue in effect for more than two years only if such continuance is specifically approved at least annually by the directors of the fund, including a majority of those who are not affiliated with the adviser, or by the stockholders. ${ }^{13}$ Obviously, any substantial amendment of the advisory agreement would be treated as a new agreement which would have to be submitted to stockholders. The act further provides that any investment advisory agreement must be subject to termination, without penalty and on not more than sixty days' notice, by the board of directors or by vote of the stockholders, and that it must terminate automatically upon assignment. ${ }^{14}$ Assignment includes by definition the transfer of a controlling interest-presumptively more than twenty-five per cent of the voting stock-in the advisory corporation. ${ }^{\mathbf{1 5}}$

This somewhat curious arrangement under which individuals act in dual capacities-often spoken of as wearing two hats-probably arose from a fear in the preInvestment Company Act of 1940 days that a true management contract, with authority to buy and sell resting in the manager, might constitute an unlawful delegation. Prior to the act, the management or advisory contracts of investment companies, including closed-end companies formed in the I920s, frequently ran for ten years or more, were assignable and had no provision for early termination on

12 Inv. Co. Act $\oint_{2}(a)(19)$.

${ }^{13}$ Inv. Co. Act $\$$ I5(a), (c).

24 Inv. Co. Act $\$$ I5(2)(3), (4). Originally, the Securities and Exchange Commission took the position that the sale by a director of a fund of a controlling block of stock in the advisory company at more than asset value constituted 2 gross abuse of trust. However, in SEC v. Insurance Sec. Inc., 254 F.2d 642 (9th Cir. 1958), cert. denied, 358 U.S. 823 (1958), the court dismissed a complaint based on this contention. See also Krieger v. Anderson, 173 A.2d 626 (Del. Ch. 1961), motion for rearg. denied, 177 A.2d 203, aff'd, 182 A.2d 907 (Del. Sup. Ct. 1962); Jaretzki, The Investment Company Act: Prob. lems Relating to Investment Advisory Contracts, 45 VA. L. REv. 1023 (1959).

25 "Assignment": Inv. Co. Act $\$ 2(a)(4)$. "Control": Inv. Co. Act $\$ 2(a)(9)$.

Some thorny questions remain as to what constitutes an assignment. The act speaks of a "transfer" of a controlling block. Suppose, however, that an individual buys a total of $26 \%$ of voting stock from ten unrelated persons. There would seem to be the acquisition of "control." But has there been a transfer of a "controlling block"? Or a purchase is made of $20 \%$ from an individual and much later $6 \%$ more from the same person in an entirely unrelated transaction. Or, let us say, $26 \%$ is sold by a controlling person to ten unrelated persons. A controlling amount has been sold, but not as a block. Or the owner of $60 \%$ sells $26 \%$, retaining $34 \%$. Obviously, the seller retains actual control. But is this a technical assignment? A determination by the SEC under $\$ 2$ (a) (9) would remove any question. Obviously, in all these situations it is better to play safe where possible. 
the part of the company. Under these circumstances, the danger that the directors of the fund might be deemed to have abdicated their responsibilities was real.

Under the requirements of the Investment Company Act, namely, that the advisory or management agreement can run initially for only two years and thereafter has to be renewed annually and that the fund can terminate the contract at any time on sixty days' notice without penalty, there would no longer seem to be any danger of such a contract constituting unlawful delegation. This would be particularly true if it were made clear that the manager was at all times subject to direction from the board of directors and if the board of directors actively kept informed and reviewed the actions of the adviser. Furthermore, as previously noted, the true management type of contract is specifically recognized-and thus perhaps authorized-by the Investment Company Act. Recently there has been a tendency towards this type of contract which in many cases would seem to conform more realistically to the fact.

\section{IV}

\section{Composition of the Board and Election of Directors}

The Investment Company Act contains specific provisions with respect to permissible affiliations of directors with the investment adviser and the principal underwriter, as well as with brokers, banks, and investment bankers. These are: (I) no more than sixty per cent of the directors may be persons who are investment advisers, affliated persons of the investment adviser, or officers or employees of the fund; (2) a majority of the directors must be persons who are not principal underwriters for the fund or affiliated persons of the principal underwriter; (3) a majority of the directors must be persons who are not regular brokers for the fund or affiliated persons of any such broker; (4) a majority of the directors must be persons who are not investment bankers or affiliated persons of any investment banker; and (5) a majority of the directors must be persons who are not officers or directors of any one bank. ${ }^{16}$ The term "affliated person" is defined in the act. Any officer, director or employee is an affiliated person of the organization with which he is so connected. An investment adviser is an affiliated person of the fund which it advises. However, the organizations of which officers, directors, employees and investment advisers are affiliated persons are not themselves affiliates of such individuals or entities. On the other hand, in respect of five per cent owners of stock and controlling persons the affliation works both ways, that is to say, both the owner and the companies

${ }^{10}$ Inv. Co. Act $\$$ ro(a)-(c).

An exception is made for mutual funds in which the investment adviser is engaged principally in the business of rendering investment advice to individual accounts and does not receive an annual management fee of more than one per cent of the average net assets of the fund for the year, in which no sales load or commission is charged to the purchaser of shares, and in which all executive salaries, expenses and office rent are paid by the investment adviser. In such cases the only requirement is that at least one director be a person who is not an officer or employee of the fund and who is not affiliated with the fund's investment adviser. Inv. Co. Act $\$$ ro(d). 
whose stock is owned are affliated persons of each other. ${ }^{17}$ Non-affliated directors are often referred to as independent directors.

It is normally the prerogative of the stockholders to elect directors. With exceptions not here pertinent, vacancies in the board which occur between meetings of stockholders may be filled by the board of directors itself. (The Investment Company Act places a limit, one-third, on the number of directors who may be elected by the board.) ${ }^{18}$ Clearly the board of directors, not only in instances where it fills vacancies itself but also in submitting a proposed slate to stockholders, bears responsibilities with respect to the composition of the board. To the extent that a director is counted as a non-affiliated director, those directors electing or nominating him should satisfy themselves that he meets this requirement and will exercise his own independent judgment on matters coming before the board.

Candidates for director are sometimes proposed by a nominating committee of the board, or by non-affliated directors, but more commonly suggestions are made by the existing management. ${ }^{19}$ This is appropriate and proper, and neither this factor nor the fact that the proposed director is well known to or friendly with the management should in itself cast any doubt on his independence. Any suggestion from whatever source should of course be thoroughly considered and discussed by the directors, each of whom should satisfy himself that the proposed director is properly qualified. ${ }^{20}$ Basically it is the stature and the integrity of the candidate which should be decisive. Beyond this, directors must be persons believed to be competent to perform the functions of directors of the fund. This does not mean that each one must be an expert in the field of investments. Persons in other industries, for example mining and chemicals, former military and naval officers, teachers and lawyers, may contribute substantially to the composite judgment of the board as a whole.

\section{$\mathrm{V}$}

\section{MANAGEMENT OF INVESTMENTS}

As the primary business of a mutual fund is the investment and reinvestment of its assets, it follows that the most important function of the board of directors is to

${ }^{17}$ Inv. Co. Act $\S_{2}(\mathrm{a})(3)$. The Securities and Exchange Commission takes the position that at least for the $60 \%$ rule, lawyers in the position of general counsel are employees and thus affiliated persons.

${ }^{28}$ Inv. Co. Act $\$ I 6(a)$.

${ }^{10}$ The affiliated directors.

${ }^{20}$ Recognizing the importance of certainty as to the classification of directors of an investment company as affiliated or non-affiliated persons, the Investment Company Act provides that a natural person shall be presumed not to be a controlled person (and therefore not an affiliated person for that reason alone), and that any such presumption, though rebuttable by evidence, shall continue until a determination to the contrary is made by the Securities and Exchange Commission. Inv. Co. Act, $\$ 2$ (a) (9). Unfortunately the Commission has stated, in dictum, that a determination of this nature may be made with retroactive effect. Matter of Fundamental Investors, SEC Investment Co. Act Release No. 3596 (Dec. 27, 1962). It is to be hoped that the courts will not follow this dictum (and thereby defeat the purpose of the provision) or that through legislation Congress will reiterate its original intent to the contrary. 
make certain that these operations are carried out competently and within the scope of applicable limitations both governmental and self-imposed. ${ }^{21}$ This is equally true whether the fund is managed by an internal staft of officers and employees or by an external adviser who either manages the fund or gives investment advice and furnishes offices and personnel. In both cases directors should satisfy themselves as to the depth of management and continuity of personnel and should know the number and functions of the various people constituting the staff, for example, the number of senior and junior analysts, the division of functions, and so on.

It is not the duty of the board itself specifically to select each individual security for purchase or sale. It is sufficient if the directors are satisfied that purchases and sales are competently handled either by the officers of the company or by the investment adviser under whatever general directions they may wish to impose and pursuant to the objectives of the fund and the limitations to which it is subject. In the case of some funds, the directors do actually pass in advance upon the purchase and sale of securities either by specific authorization, the establishment of an approved list or otherwise. In other cases, an executive committee of the board of directors or a portfolio committee of the board functions in this respect, reporting to the board. However, it is sufficient if the directors are kept currently advised of purchases and sales made by the appropriate officers of the fund, or the investment adviser, as the case may be, and are periodically informed of the reasons for the investment decisions. Generally speaking, it is advisable that the directors meet monthly, but there is no absolute rule. In situations where purchases and sales are infrequent, it may be appropriate for the directors to meet less frequently and possibly, with a true management contract in which the manager has discretion over purchases and sales, less frequent meetings would suffice.

Within and in conformity with the general limitations applicable to the fund, the overall responsibility for formulation and implementation of investment policy lies with the fund's board of directors. It follows that the directors should be gen-

\footnotetext{
${ }^{22}$ Limitations on permissible investments and investment activities may be imposed from various sources. The Investment Company Act contains specific prohibitions with respect to investments in securities of other investment companies, insurance companies, brokers, dealers, underwriters, and investment advisers, Inv. Co. Act $\$ 12(d)$; with respect to underwriting commitments by diversified companies, Inv. Co. Act $\$ 12$ (c); with respect to loans to affiliated persons, Inv. Co. Act $\$ 21(b)$; and with respect to investments in voting securitics which result in cross-ownership or circular ownership, Inv. Co. Act $\$ 20$ (c). Any limitations on concentration of investments in particular industrics, purchase and sale of real estate and commodities, portfolio turnover or any other fundamental policies which are set forth in the fund's registration statement may not be changed without stockholder approval. Inv. Co. Act. $\$ 58($ b) (1)-(2), 13. Diversified investment companies are similarly prohibited from becoming nondiversified without stockholder authorization. Inv. Co. Act. $\S 1_{3}(\mathrm{a})(\mathrm{I})$. State blue sky laws may impose further substantive limitations-Wisconsin, for instance, has prohibited at least one fund from investing in securities of any corporation which has an interlocking director with the fund, Wis. Dep't of Securities, Monthly Bull. (May, 1958), 2 CCH Blue SkY L. REP. \$ 52,623.03 (1960) - or may require that such further limitations be contained in the articles of incorporation or by-laws. See, e.g., Ohio, Reg. Q.3, 2 CCH Blue SKY L. ReP. I38,653 (1954). In practical effect, further limitations stem from the Internal Revenue Code. For example the fund may not qualify for special treatment as a "regulated investment company" unless its assets meet the standards of diversification set forth in 5851 (b) of the Internal Revenue Code of 1954.
} 
erally familiar with the fund's articles and by-laws and its registration statement, and have the collective responsibility to require that the fund's management make investment decisions which adhere to all applicable restrictions. Under normal circumstances, the director may look to the management, whether internal staff or investment adviser, and counsel to implement these provisions, but it might be well to require periodic, say annual, reports on these subjects.

In view of the redemptive privilege available to shareholders, it is important that a degree of liquidity be maintained at all times. That means that a suitable portion of its holdings should be securities which have a ready market, the amount depending upon the nature of the fund, the constitution of its portfolio and general conditions which might affect the possibility of substantial liquidations.

\section{VI}

\section{INVESTMENT AdVISORY CONTRACTs}

As we have seen, the advisory contract must initially be approved by stockholders. The approval embraces not only the terms of the contract, including the amount or rate of fee, but most important of all involves approval of the particular investment adviser chosen. Normally, the adviser is chosen and the terms of the advisory agreement established, subject to early confirmation by stockholders, by the sponsor of the fund who is apt to be the adviser itself. Shares are, accordingly, bought, both initially and from time to time thereafter pursuant to the continuous offering of the shares, with knowledge of the terms of the advisory agreement, including the fee, and particularly of the adviser selected. In fact, not infrequently the shares of the fund are bought because of confidence in the adviser and sold with emphasis on the management. This is particularly evident where the fund bears the name of the adviser. ${ }^{22}$

While the stockholders of a fund must initially approve an advisory agreement, this agreement may run only for a period of two years unless thereafter annually approved either by the board of directors of the fund or by the stockholders. Furthermore, both the directors and stockholders have the power to terminate the contract without penalty at any time upon sixty days' notice. The consideration of the renewal of the advisory contract, whether determined by the board of directors or submitted for action to stockholders, is an extremely important function of the board of directors. The board must satisfy itself of the integrity of the adviser, that it has performed competently and that the fee is reasonable. In reaching its decision it must act independently and honestly and must be in possession of sufficient facts to reach a reasonable determination. The consideration of the reasonableness and desirability of the advisory contract is not something that comes to the attention of the directors only once a year and is then put on the shelf for

${ }^{25}$ For example, Bullock Fund, Ltd., Dreyfus Fund, Inc., the Eaton \& Howard funds, The Lazard Fund, Inc., Loomis-Sayles Mutual Fund, Inc., the Scudder, Stevens \& Clark funds, and The T. Rowe Price Growth Stock Fund, Inc. 
another twelve months. It is something that is, sometimes directly and sometimes indirectly, in the minds of directors throughout the year as they observe the competence and integrity of the adviser and from time to time hear about the fee structure in the industry. Among the factors to be considered as relating to the reasonableness of the fee are the charges of comparable funds, fees charged for similar services in other situations (although it must be remembered that in the case of mutual funds the fee generally covers the furnishing of management personnel and office space for all operations of the corporation as well as the giving of investment advice), the responsibilities assumed by the adviser, the size of its organization and the undesirability of disrupting existing relationships. Occasionally inquiry into the profits realized by the adviser may be in order, but normally this is a minor factor, if pertinent at all-for example if the fee is clearly low in relationship to the services performed. Otherwise, the most inefficient manager who earned the smallest profits would be deserving of the biggest fee, while the efficient manager, although possibly effecting top performance, would be entitled to the smallest compensation. The directors are not required to choose the best possible management or to insist upon the cheapest fee. There is wide latitude for difference of opinion as to relative competency of management. As to the fee, it is the duty of the director to see that the fee is reasonable in relationship to the services performed. One does not insist on having the cheapest lawyer, physician, or other professional.

While it may be relatively easy to formulate the responsibility of a board of directors to satisfy itself that the management is competent and the rates reasonable, the board of directors does not act in a vacuum. To begin with, the stockholders either have chosen the existing management or have bought their shares in probable reliance on such management. Presumably, they have confidence in the management and would not expect the directors to take action to change it except in unusual circumstances. This in itself is a limitation on the bargaining power of the directors with respect to the advisory agreement. Furthermore, while the directors may cancel the advisory agreement, they cannot of themselves retain a new adviser. This requires stockholders' approval. ${ }^{23}$ The directors might submit to stockholders the selection of a new adviser with a recommendation for a favorable vote and not cancel the existing contract until after a new adviser is chosen, but this could be a cumbersome procedure and could be disquieting to stockholders. A presumption results in favor of the continuance of the existing adviser. The theoretical discretion of the board of directors is thus severely limited in actuality. Where, for example, the directors might feel that management needed strengthening in some area or that compensation was beginning to approach a high level, probably all that can be expected of directors is to bring pressure for strengthening of personnel and for reduction of fees, where thought desirable. ${ }^{24}$

${ }^{28}$ Inv. Co. Act $\$ I_{5}(\mathrm{a})$.

${ }^{24}$ See also Lobell, The Mutual Fund: A Structural Analysis, 47 VA. L. REv. 181, 211-13 (1961). 
One commentator conceives of a mutual fund as a cluster of individual investment advisory accounts. From this idea he argues that conceptually the directors have no responsibility or function with respect to the management contract and later he reaches this as a legal conclusion. ${ }^{25}$ But the fact is that even if a mutual fund were only an aggregation of individual advisory accounts, which it is not, once a fund has adopted the corporate form, the corporate consequences of responsibilities follow. Beyond that, the Investment Company Act specifically authorizes action by directors on advisory contracts.

A situation somewhat different from that of periodic renewal arises where an advisory contract has terminated by "assignment." The usual case of assignment arises out of the sale of a controlling block of the stock of the investment adviser. The purchaser of this stock buys it with the expectation that a new contract with the adviser will be submitted to stockholders for approval, and will be approved. It may be that the personnel of the existing investment adviser will continue intact, it may be that a totally new management will be installed or it may be that the adviser will continue with some of the old personnel and with important additions or substitutions. Whatever the circumstances, these must be disclosed fully to the stockholders in submitting a new contract for approval. Some recommendation should be made by directors to stockholders and presumably the purchasers of stock in the advisory company would not commit themselves to do so unless they had assurances of favorable recommendation by the directors. Such assurances are entirely proper in themselves, if merited. While the new contract results from stockholders' action, the duties and responsibilities of the directors in submitting the agreement to stockholders are as great as where the directors themselves take the entire responsibility in an annual renewal of the advisory agreement. In some respects they have greater freedom of action in the case of assignment, because if they were to look unfavorably upon a new contract, the sale of stock resulting in assignment would probably not take place. To the extent that directors have greater freedom of action, their responsibility may be even greater. The same criteria of competency and integrity of management and reasonableness of fee would apply.

The role of the affliated director in relationship to the advisory contract is one that has given rise to some confusion. Take, for example, an individual who is a director both of a fund and of its investment adviser. It has been suggested that where the adviser is a publicly held corporation, the common director owes conflicting loyalties to the shareholders of the two companies. But it makes no difference whether the stock of the advisory corporation is publicly held or not. Whatever duty the director owes to the stockholders of the advisory company, he owes whether

Jarctzki, The Investment Company Act: Problems Relating to Investment Advisory Contracts, 45 VA. L. REv. 1023 (1959).

${ }^{35}$ Lobell, The Mutual Fund: A Structural Analysis, 47 VA. L. Rev. 181, 185 (1961). Lobell, Rights and Responsibilities in the Mutual Fund, 70 YALE L.J. 1258, 1282 (x961). 
the stock is widely distributed or closely held. Normally, he will stand aside and leave the determination of the fees and continuation of the manager to the nonaffliated directors. But he cannot completely divest himself of his responsibilities to either side. He owes a duty to the fund of which he is a director to see that there is no overreaching on the part of the adviser with which he is affiliated or may be a member. This is compatible with any duty he owes to the adviser. Neither he nor any other director of the adviser owes it a duty to secure excessive fees. Conversely, he owes no duty to the fund to secure investment advice on unreasonably low terms. Within these limits he may stand aside and leave the determination to the non-affiliated directors. ${ }^{26}$

\section{VII}

\section{The Principal Underwriters and Retail Sales Practices}

The policy of the disclosure requirements of the Securities Act of $x 933$ is obvious-to insure that prospective investors have adequate information with respect to what they are buying. Beyond this, the responsibility of the fund director with respect to retail sales practices has received but little consideration in the past. The fund does not itself employ salesmen nor does it sell directly to the public. These functions are exercised by the principal underwriter which acquires new shares from the fund at net asset value pursuant to its underwriting contract and then sells the shares either to a dealer which in turn retails the shares to the public, or in some cases directly to the public through its own retail sales force, or by a combination of these methods. Whether the underwriter acts as agent or principal, the retail dealers as a matter of practice purchase as principal.

In view of this distribution procedure, the contact between salesman and investor has seemed remote from the proper orbit of the fund directors. Accordingly, the industry was startled at the statement of Allan F. Conwill, Director of the Securities and Exchange Commission's Division of Corporate Regulation, that mutual fund directors were not immune from responsibility for inadequately trained salesmen and improper selling methods. ${ }^{27}$

As already noted, the Investment Company Act requires approval by the directors of all contractual arrangements between the company and the principal underwriter. In passing upon the underwriting agreement, the directors are periodically called upon to satisfy themselves as to the competence and integrity of the principal underwriter. The principal underwriter in turn selects the dealers

\footnotetext{
${ }^{20}$ In this connection it may be interesting to note the differing standards of the Investment Company Act and normal state law. Thus, we have seen, at least in the eyes of the Commission, a lawyer who is general counsel is considered an affiliated person and cannot be counted in making a majority of non-affiliated persons. However, under state law he is not disqualified and he has a duty to express himself and to vote. Conversely, under the Act, any stockholder of the advisory company holding less than $5 \%$ of its stock is not defined as an affiliated person and is not disqualified to vote. But under state law the owner of any amount of stock of the advisory corporation, no matter how small, is an interested person and is subject to the same disqualifications that a $5 \%$ or greater stockholder would be.

${ }^{27}$ Conwill, The Minority Menace to Mutual Fund Selling, 18 Bus. LAw. 1055, 1060-61 (1963).
} 
with whom it enters into sales agreements. In doing so the underwriter has a similar responsibility. Finally the dealers, in employing the retail salesmen, likewise have responsibility for their competence and integrity and for proper selling methods.

Although the principal underwriter cannot be expected to police the operations of his dealers, surely the principal underwriter has the obligation to satisfy himself in some degree of the competency and integrity of the dealer's organization. In turn, the quality of the dealers employed by the principal underwriter should be a factor in the decision by the fund and its directors to contract with, or continue its contract with, the principal underwriter. Thus, while any relationship between the fund director and the retail salesman is distant, it cannot be said that the director is under all circumstances completely immune from responsibility for the character and sales methods of the individual salesmen. The director should ask to be kept informed periodically as to sales practices, and as to complaints from dissatisfied purchasers of the fund's stock.

\section{VIII}

\section{CONFLICTS OF INTEREST}

Much is said these days about "conflicts of interest" and in respect of "possible conflicts of interest" of directors. It has even been suggested that a director should not allow himself to be in a position where the possibility of such a conflict might exist. In general, the rule is a simple one: A man must not attempt to serve two masters. This, however, is merely the beginning, not the end, of the problem. In today's complex society the already narrow field of choice from which competent directors can be chosen would drastically be limited further if the mere possibility of a conflict was a disqualification. Furthermore, the conflict is satisfactorily resolved in many situations if the director in question removes himself from any participation in the consideration and determination of the issue in respect of which the conflict may exist.

As to mutual funds, the typical possibilities of conflict exist: between the investment adviser and the fund, especially in relation to the advisory fee and the duties to be performed by the adviser; between the underwriter and the fund, in that the underwriter may be unduly influenced by considerations relating to sales and salability of the fund's shares; between the fund and the broker or dealer who has a monetary interest in the volume of portfolio transactions which he executes; and also with respect to purchases and sales of securities which a director may make for his own account or for account of persons associated with him. Further possible conflicts may arise in the use of reciprocal brokerage and give-ups, in the choice of brokers, in the selection of banks for deposits and in respect of allocation of expenses between the fund and the adviser or the underwriter, as the case may be.

The Investment Company Act deals realistically with these problems. Rather than attempting to prohibit all relationships in which conflicts might arise-a course 
which would have constituted an extreme departure from common law principles and business realities-the approach of the act is based upon the more familiar concepts of independent scrutiny of the transaction and full disclosure. The first principle is reflected in the requirement, already noted, that varying percentages of the directors be persons who are not affiliated with the investment adviser, principal underwriter, brokers, investment bankers or banks, and in the further specific requirements that the investment advisory contract and the principal underwriting contract be initially and periodically approved by the stockholders or by a majority of the directors who are not affliated with the adviser or underwriter, respectively Transactions of directors dealing as principals with the company are prohibited unless the transaction has been subjected to the independent scrutiny of the Securities and Exchange Commission itself and has been found by that body to be reasonable and fair and to be devoid of overreaching on the part of any person concerned. The second principle, that of disclosure, is exemplified by the requirements that periodic reports to the stockholders state the aggregate dollar amounts of purchases and sales of portfolio securities and the aggregate remuneration paid by the fund to the directors and persons or companies with which they are affiliated. ${ }^{28}$ Further, the disclosures required in proxy statements cover a much wider area. ${ }^{2 \theta}$

However, in order for these safeguards to be effective, it is necessary that directors scrutinize these transactions and satisfy themselves that the interests of the fund are safeguarded. The management should of its own initiative bring these matters to the attention of the directors periodically and supply them with all appropriate data on the subject.

Varying situations may arise with respect to the duty of a director who knows

${ }^{28}$ Inv. Co. Act $\$ 30(d)-(c)$.

${ }^{29}$ Inv. Co. Act $\S 20(a)$. For example, there is required the name of the investment adviser, the date of the advisory contract, the date on which it was last submitted to a vote of security holders and the purpose of such submission; a brief description of the terms of the contract, including the rate of compensation of the adviser; the aggregate amount of the investment adviser's fee and the amount and purpose of any other material payments by the investment company to the investment adviser during the preceding fiscal year; the name, address and principal occupation of the principal executive officer and each director or general partner of the investment adviser; facts relating to control of the investment adviser; facts relating to the relationships or overlap between officers or directors of the investment company and those of the investment adviser; the identity of each person employed as a broker by or on behalf of the investment company in which the investment adviser, its officers, directors or partners or affiliated persons have any material direet or indirect interest; transactions in securities issued by the investment adviser, by any officer, director or nominee for election as director of the investment company; the nature of any material direct or indirect interest which any director, nominee for election as director, or offeer of an investment company has in the principal underwriter or prospective principal underwriter of the securities of the investment company; the nature of any material relationship between the investment adviser and any such principal underwriter; facts rclating to control of the principal underwriter or any prospective principal underwriter of the investment company's securities; and information describing any material interest, direct or indirect, of any officer, director, or nominee for election as a director of the investment company in any material transactions in the preceding fiscal year of the company, or in any material proposed transactions, to which the investment adviser or any parent or subsidiary of the investment adviser was or is to be a party. Rules 20a-2, a-3 of the General Rules and Regulations Under the Inv. Co. Act, 17 C.F.R. $\$ \$ 270.20 \mathrm{a}-2,-3$ (Supp. 1963). 
of contemplated investment action by a fund. Take, for example, the purchase of stock. If the proposed purchase is of stock which is available only in limited quantity, or is of a particularly large block of securities, it seems that normally the director should not compete with the fund in the acquisition of the stock. But if the proposed purchase is of a comparatively moderate amount of listed stock with a wide market, small purchases by the director would ordinarily have no measurable effect upon the purchases by the fund. The director may have other fiduciary obligations, either as trustee or as adviser for another, which cannot lightly be put aside. He should not take advantage of information obtained from the fund, but the decision of the fund to buy may be a composite judgment in which he has participated or a like decision may have been arrived at by the director independently. Surely he cannot withhold his judgment from others to whom he has a fiduciary obligation. This is an area in which one cannot generalize. Each situation must be decided in good faith. ${ }^{30}$

\section{IX}

\section{Miscellaneous Itears}

In the case of corporations engaged in other types of businesses, the consideration of the amount and timing of dividends is generally an important function of the directors. This is not true in the case of mutual funds. The federal income tax law as applied to the funds, in order to avoid double taxation, first of the income . and profits received by the fund and then again on the same income and profits in the form of dividends received by stockholders, credits the fund with all taxable dividends paid to stockholders, including dividends from realized capital gains. ${ }^{31}$ Thus, if a fund pays out all such income and profits, it pays no federal income tax. The fund is treated as a conduit for the receipt and distribution to stockholders of income and profits. It follows that the payment of these distributions is for the most part automatic and involves little discretion on the part of the directors.

One caveat should be made, however. That is with respect to the realization of capital gains. These should be taken for investment reasons only, and not with an eye towards distributions to shareholders. Unfortunately, except in cases of sophisticated investors, there is a confusion in the minds of shareholders as to the nature of capital gains distributions. They are apt to think of them as a part of the return on their investment, instead of a return of a part of their investment, which they really are. In fact, investors have been known to buy stock in mutual funds just prior to the distribution of capital gains, not realizing that what they

\footnotetext{
${ }^{30}$ The Investment Company Institute in its "Guide to Business Standards" provides as follows:

"When the appropriate persons have determined to purchase or sell a specific security for the portfolio of a member investment company or companies, or have such action under immediate consideration, no officer, director or employee of the investment company or companies or of the investment adviser who knows of such determination or consideration should take any action in connection therewith which is inconsistent with such person's obligations to the investment company or companies, giving recognition, however, to any other fiduciary responsibility imposed upon such person."

${ }^{21}$ INT. REv. CODE of $1954 \$ \$ 852($ b) (2)(D), (b) (3)(A) (ii).
} 
were doing was paying a sales charge on a part of their investment which was about to be returned to them. Directors must be alert to counteract any tendency on the part of a sales-minded management to recommend or effect sales of stock for the purpose of generating capital gains with a view to increasing the salability. of the fund's shares.

Reference has already been made to proxy material. Control of the proxy machinery, as it is termed, is a very important responsibility of the directors. Normally, the power to submit proposals to stockholders is the power to determine the issue submitted. For the most part, normal action taken at annual stockholders meetings is considered routine-the election of directors and the ratification of auditors chosen by directors. ${ }^{32}$ The important responsibility of directors in submitting a slate of directors has already been discussed. Their role in the selection of auditors is obvious. That is normally the function of the board, and the submission to stockholders adds little if anything except to pin-point the responsibility of the accountants directly to shareholders as well as to directors of the fund. As to other matters, whatever the relative importance, the general rule applies that the directors have a substantial responsibility in submitting matters to stockholders, even though the ultimate decision is that of the stockholders. Normally, any submission to stockholders involves in effect a recommendation on the part of directors. Complete disclosure is vital. As in other situations discussed, independent judgment, reasonably arrived at after consideration of all pertinent factors, is called for.

At the time of this writing, the Securities and Exchange Commission is preparing a new form of comprehensive annual report to be filed with it by each fund. This report is expected to cover a substantial part of the activities of the fund. In respect of matters which are appropriate for certification, the report will contain the certification of the independent auditors of the fund. As to other matters, they will be checked by such auditors to the extent feasible. This is intended both to enable the staff of the Commission to check on the activities of the individual funds and as a starting point for periodic field inspections. If kept within reasonable limits, this report should be useful to directors as a convenient vehicle for reviewing the procedures of the funds of which they are directors.

$\mathrm{X}$

\section{AN UNREALISTIC Approach}

It is surely not the desire of this writer to belittle the duties and responsibilities of a mutual fund director. Nevertheless, an unrealistic approach to this subject can do more harm than good. If the extent of these duties and responsibilities were pressed to a point where they could be fulfilled only by an expert and require an inordinate amount of time, the choice of non-affiliated directors would be so limited as to curtail even further the availability of competent persons of broad

${ }^{32}$ Inv. Co. Act $\$ 32(a)(2)$. 
background. $^{33}$ The time required in the exercise of their duties would bring the composition of a board very close to a purely management group. The benefit of breadth in the directorship would be lost.

A trustee of a mutual fund (not a lawyer) has set down his ideas of "The Role of the Independent Trustee of a Mutual Fund."34 He would require: As to qualifications, "[H]e should have no conflict of interest such as active association with an organization, bank, or brokerage house doing business with the fund. . . . He should have a background of experience in or with business affairs, as a sound basis for investment judgment," "adequate time to devote to the fund's affairs," and "he should be thoroughly capable of forming his own personal opinions on investment matters and of expressing them effectively." This would prohibit affiliations permitted by the Investment Company Act. Furthermore, as has previously been noted, in a well rounded board there are attributes which would qualify a particular director who could not meet the above specifications.

In respect of his duties, it is suggested that a director must

study assiduously the general course of business in this country and in the world, the probable trend of legislation, the political scene, the advent of new important technological advances, and economic subjects such as the business cycle, as a basis for sound judgment regarding the investments of the fund.

He is expected to pass judgment "on every important action . . . and the general rule should be that action is taken only after board approval." As a member of the board he is expected "to be alert to insure that legal affairs of the fund are conducted strictly in accordance with the law and the regulations of the SEC." $\mathrm{He}$ is expected to maintain at all times with "all the personnel associated with the fund, relations such as are conducive to mutual respect and genuine collaboration." Further, he is expected to have an intimate knowledge of the capability and qualifications of the persons comprising the management organization and it is suggested that it is "especially desirable that the Management personnel, including the younger members, should meet with the trustee under circumstances where the trustees are reviewing recommendations made and supported by the Management." Obviously, this would require more time than normally can be expected of a busy man with other prime commitments.

If the foregoing were merely an enumeration of what its author conceives to be the qualifications and duties of an independent trustee of the funds with which he is associated, no comment would be appropriate. But he purports to speak in general terms. Standards such as those enumerated are not only unrealistic but

\footnotetext{
${ }^{23}$ Under a ruling of the Federal Reserve Board, no officer or director of a member bank may serve as a director of a mutual fund that is currently issuing its shares. I2 C.F.R. \$2I8.I0I -.107 (Supp. 1964). This eliminates from the mutual fund boards a large number of men of stature and experience from whom are drawn the membership of the boards of member banks.

${ }^{36}$ The author is Dr. Vannevar Bush, trustee of the George Putnam Fund of Boston and the Putnam Growth Fund. The Putnam Management Company, Inc., Boston, Mass., distributes the pamphlet containing Dr. Bush's ideas. See note 4 supra as to the similarity of "director" and "trustee."
} 
would seriously curtail the availability of competent and desirable persons to serve on mutual fund boards. It suggests that the compensation of such a director would more nearly approach that of a full time associate than what is normally paid to a non-affiliated director.

\section{CoNCLUSION}

In conclusion, it seems clear that the duties and responsibilities of the directors of a mutual fund are considerable and should not be lightly assumed. To exaggerate them, however, is a service to no one. Probably the most important protection from a director's point of view is the integrity and competence of the management, be it internal or external. With these attributes, the director should be able to rely with confidence on the management in respect of many things. By definition, a non-affiliated director is not a full time associate either of the fund or its adviser. He cannot be expected independently to assemble information or prepare elaborate studies on even important matters as to which he is required to exercise business judgment. He must necessarily depend upon information submitted to him by management.

The independent auditors, within their sphere, are a great protection to the directors. It is important that the fund have good counsel to whom the directors should be able to look for guidance in the performance of their duties. Finally, their responsibilities may be roughly divided into two categories. The first relates to matters which may require checking. ${ }^{35}$ The second covers matters on which they must exercise judgment. The latter requires primarily independence, adequate information and common sense.

As previously stated, the duties and responsibilities of mutual fund directors derive basically from state law. To the extent that directors have the responsibility for particular matters in the operation of a fund, provisions of the Investment Company Act regulating the funds in that area necessarily affect the duties and responsibilities of directors. Beyond that, in certain instances, specific duties are imposed. ${ }^{30}$ These specific duties cannot properly be enlarged by rules and regulations of the Securities and Exchange Commission. For example, it is beyond the authority of the Commission to insist that any particular action be approved by the board of directors and more particularly by specified members, except as provided in the act. Unless so provided, these are matters governed by state law. Nor would it be a service to mutual fund stockholders for the Commission to attempt to enlarge these specific responsibilities, to demand that directors accept personal responsibility for matters with which directors ordinarily are not directly concerned, or in other ways to place upon directors additional burdens not included in the act as it now stands. This would greatly increase the existing difficulty of obtaining responsible men to act as independent mutual fund directors.

${ }^{85} \mathrm{Sec}$, for example, matters enumerated in note 21 stupra.

${ }^{88}$ See, for example, the requirements of $\S 15$ of the act with respect to voting on advisory and underwriting contracts. 